be new procedures for research clearance which have just been put forth. Until now, the University had full authority in this domain; approval by the appropriate faculty sufficed. Henceforward, in addition to university support, clearance from the Ministry of Foreign Affairs is also mandatory. What remains unclear is what procedures the Ministry will follow in processing requests. Until all of this is worked out, those hoping to undertake research projects in Zimbabwe can anticipate delays. All sources insisted that it would be very unwise to take advantage of the absence of a visa requirement to simply go to Zimbabwe, in the hope that problems could be worked out on the spot. In spite of the likely bureaucratic difficulties the new procedures will create, my sense was that Zimbabwe continues to be receptive to foreign scholars. Finance and Planning Minister Chidzero, in his major address to the conference, insisted that Zimbabwe was an "open book;" he invited all and sundry to consider its experience as a laboratory of development.

The three-day Ivory Coast stopover was sliced to two by a missed plane connection in Lagos. I participated in a "diner-debat" organized at the residence of Ambassador, on the theme of American policy in Africa; in attendance were several university staff, deputies, journalists, and representatives of the Ministry of Foreign Affairs. There was also an hour-long television appearance on the same theme, where I was grilled by three Ivoirien journalists. It was made clear in these events that I was speaking only on my own behalf, and not as representative of the Association.

Of the university contacts, the most useful was with the former Dean of the "Sciences Humaines" faculty, Lansine Sylla. He would be very helpful to visiting American scholars, of whom there are relatively few. Robert Mortimer was there as a Fulbright professor last year; his article in the latest (January-February 1983) issue of AFRICA REPORT gives a useful overview of the general situation, which closely coincides with my own impressions.

\title{
OBITUARIES
}

Jo W. Saxe

Jo W. Saxe, 57, an economist and senior adviser for balance of payments at the World Bank, died on November 19, 1982.

Mr. Saxe, who was born in Philadelphia and attended the University of Pennsylvania, was regarded as an expert in balance-of-payments accounting for developing countries. He had been at the World Bank since 1968 and was the former chief of its international finance division.

From 1961 to 1965 , Mr. Saxe served as senior adviser for development finance at the Organization for Economic Cooperation and Development in Paris. Also in the 1960s, he was administrator of multilateral-aid programs for the U.S. Agency for International Development and served as adviser to the U.S. State Department Bureau of Economic Affairs.

In the 1950s and early 1960s, Mr. Saxe was associated with the Center for International Affairs at Harvard University, where he was an adviser and traveled to several countries to help select fellows for the program. He was also a consultant to the Ford Foundation and headed several economic missions for the U.S. government.

Mr. Saxe worked for the French Ministry of Finance in 1958, specializing in the economic problems of French-speaking African countries. From 1959 to 1961 , he was adviser to the prime minister of Togo for the United Nations. 
Mr. Saxe was a fellow of the African Studies Association, a member of the American Economic Association and the Society for International Development. He served as an elected member of the World Bank Credit Union and was on the governing board of the World Bank Pension Fund. He authored numerous articles in his field.

from The Washington Post, November 21, 1982.

\section{S.J.L. Zake}

Dr. Joshua Zake statesman, lawyer, anthropologist, author died on October 19, 1982 in Kampala where he was born on February 28, 1922.

His degrees included a B.A. from Fort Hare, an L.L.B. from the University of London where he became barrister at law at Gray's Inn. Later he was awarded a Master's degree in comparative law at the University of Chicago and a doctorate in anthropology at Northwestern University in 1962. His dissertation was entitled: "Approaches to the Study of Legal systems in Nonliterate Societies". Soon afterwards he returned to Uganda to be appointed Minister of Education and acting Attorney General within the first Obote government. After Amin's coup Dr. Zake fled from Uganda and began teaching first at the University of Utah and more recently at Governor's State University in Park Forest South, Illinois. Dr. Zake served briefly as his country's ambassador to the United States after Amin's fall. He was a prolific writer. His works include early nationalist pamphlets and more recently several works of fiction.

Our sympathy is extended to his wife, Margaret and their four children one of whom, Diana, is a student at Northwestern, and to his many friends the world over.

Hans E. Panofsky

Northwestern University

Evanston, Illinois, U.S.A.

\section{OP ED}

(With the following articles, ASA News inaugurates an Opinion section which we hope will attract essays from every quarter of Africanist thought-editors)

\section{REVISITING THE CUBAN MILITARY PRESENGE IN ANGOLA}

Opoku Agyeman

Assistant Professor of Political Science

Cornell University.

Many false assumptions and distortions surround Angola these days, and no where more so than on the matter of the continuing Cuban military presence in that land-an issue used by protagonists of every description to serve ulterior motives.

Consider the American position. Since the Cuban 1975 entrée into the civil war that would end in the triumphant installation of an MPLA government in an independent Angola, successive US Administrations, viewing the issues through the customary narrow prism of East-West rivalry, have cited Angola as a proof of Soviet expansion in Africa and have, on the account, refused to recognize the MPLA regime until the Cubans, the presumed Soviet proxies, are removed. And yet the implication here of Soviet sway in Angola 